\title{
FIELD GUIDE TO
}

SHARKS, RAYS

\& CHIMAERAS

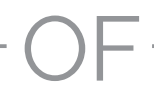

EUROPE AND THE

MEDITERRANEAN

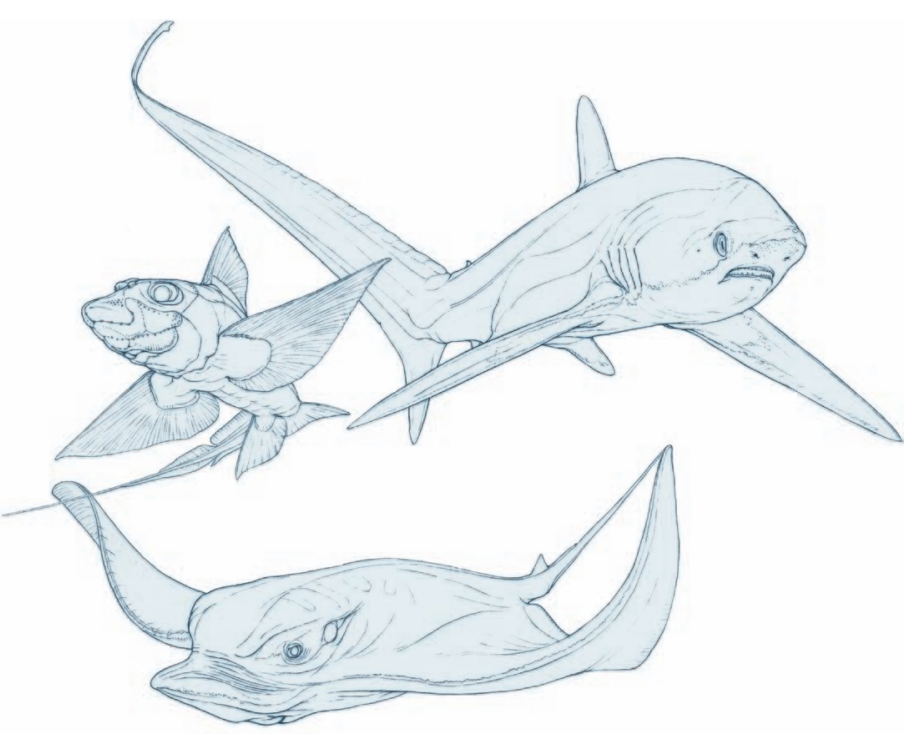

David A. Ebert and Marc Dando 
Published by Princeton University Press,

41 William Street, Princeton, New Jersey 08540

In the United Kingdom: Princeton University Press, 6 Oxford Street,

Woodstock, Oxfordshire OX20 1TR

press.princeton.edu

Princeton University Press is committed to the protection of copyright and the intellectual property our authors entrust to us. Copyright promotes the progress and integrity of knowledge. Thank you for supporting free speech and the global exchange of ideas by purchasing an authorized edition of this book. If you wish to reproduce or distribute any part of it in any form, please obtain permission.

Requests for permission to reproduce material from this work should be sent to Permissions, Princeton University Press

Copyright (c) 2021 by Princeton University Press Illustrations copyright (c) 2021 by Marc Dando

Copyright in the photographs remains with the individual photographers. All rights reserved. No part of this publication may be reproduced, stored in a retrieval system, or transmitted, in any form or by any means, electronic, mechanical, photocopying, recording, or otherwise, without the prior permission of the publishers.

British Library Cataloging-in-Publication Data is available

Library of Congress Control Number 2020944541

ISBN 978-0-691-20598-4

Ebook ISBN 978-0-691-21182-4

Production and design by WILDNATUREPRESS Ltd., Plymouth, UK Printed in Italy 